\title{
Digital economy and transformation of personnel training for AIC
}

\author{
F.T. Nezhmetdinova ${ }^{1, *}$, G. R. Fassakhova ${ }^{1}$, L. R. Shagivaliev ${ }^{1}$, N. Kh. Sharypova ${ }^{1}$, and R. I. Zinurova ${ }^{2}$ \\ ${ }^{1}$ Kazan State Agrarian University, 420015 Kazan, Russia \\ ${ }^{2}$ Kazan National Research Technological University (KCTI), 420015 Kazan, Russia
}

\begin{abstract}
The article presents the results of research into the impact of the digital economy and Industry 4.0 on the education system as a global mechanism and on the tangible segment of the sectoral economy agriculture. The aim of this study is to determine the main directions of education system transformation both structurally and substantively under the influence of the digital economy and Industry 4.0. According to the results obtained, Russia's entry into the digital world system is hindered by a number of factors, including the lag of the Russian Federation from world's major economies in breakthrough technologies, the shortage of staff with specialization in "Industry 4.0" and the level of digital culture development. The development of agro-industrial complex's digital economy, provided by modern technologies, including robotics and artificial intelligence, entail high productivity, increased efficiency, safety and convenience. But on the other hand, it also raises complex questions about the broader impact of digitalization on the labor market in the agro-industrial complex, skills and competencies.
\end{abstract}

\section{Introduction}

The Russian Federation and the Republic of Tatarstan faced amplifying globalization and transition of the economy to a new technological mode. The 21 st century is becoming the century of high technology and high living standards.

The global common economic, legal and information space is rapidly developing. Aggravation of global competition includes not only well-established markets of funds, goods, labor force and technology, but also affects the levels of national governance, stimulation of innovation and human capital development [1-4].

The main global challenges may be outlined as follows:

- Transition of the world economy to a digital form and to a new technological mode of Industrialization 4.0 .

- Increase of the speed of technological development of the global economy. In these conditions, Russia competes not only with the leading countries in the field of breakthrough technologies, but also with the BRICS, CIS and other countries.

- Global-scale competition for conditions promoting the competitiveness of innovative economies, namely, for highly qualified staff and "smart" resources (investments in new knowledge and technologies, competencies and skills), advanced education and competence centers.

- Global challenges that face not only Russia, but the humanity as a whole - climate change and food security, environmental pollution and the growth of military threats, population aging and health problems [5, 6].

Both content and structure of the education system were influenced by two waves of the digital revolution $[8,9]$. This is due to the uneven involvement and introduction of digitalization during the last 50 years in different countries - from developed to developing. The first wave involves the creation of computers and software capable of processing large amounts of information and replacing human commands with systems capable of simple, and then much more complex calculations.

The second wave is associated with the fourth industrial revolution, when the combination of technologies blurs and converges the boundaries between the physical, digital and biological spheres [10, 11]. Klaus Schwab comments on this in his report "Industry 4.0" (2016). Developments in digital technology, genetics, artificial intelligence, robotics, nanotechnology, 3D printing and biotechnology are reinforcing each other. Special attention is paid to endto-end technologies that ensure convergence of all others. First of all, it is the digitalization of all spheres of activity and the onset of the second digital revolution. This will mark the beginning of the overall revolution, more full-fledged and comprehensive than anything we have ever seen.

Smart systems, such as houses, manufacturing enterprises, farms, nets or cities, will help tackle problems ranging from supply chain management to climate change. Enhancement of the sharing economy will provide people with the opportunity to monetize everything from their empty house to their car [12]. While the upcoming change offers great promise,

\footnotetext{
*Corresponding author: nadgmi@ mail.ru
} 
patterns of consumption, production, and employment provoke major challenges that require preventive adaptation by corporations, governments, and individuals [13, 14]. Along with the technological revolution, there is a number of broader socio-economic, geopolitical and demographic drivers of change, each interacting in multiple areas and reinforcing each other.

In the current situation, the Russia's State program "Digital economy in Russia" adopted in 2017 seems to be a logical response to global challenges. While adopting this program at the meeting of the Council for strategic development and priority projects, President of Russia Vladimir Putin pointed out that this is the issue of national security: "The digital economy is not a separate industry, in fact it is a way of life, a new basis for the development of public administration, economy, business, social sphere, the whole society," he said. "Formation of the digital economy is a matter of national security and independence of Russia, competition of Russian companies." The President of the Russian Federation put forward the task "to multiply the number of graduates in the sphere of digital economy" and "to achieve all-Russian digital literacy" [15].

The process of digitalization has affected all sectors of the economy, agriculture being one of them. Russia has developed road maps and programs for digital economy development in the agro-industrial complex, which require restructuring of the entire system of staff training.

These challenges set the agenda for shaping the requirements to the system of agricultural education, new competencies of young people and teachers. Digital economy and industry 4.0 has to be analyzed on both structural and substantive levels so as to ensure readiness to accept these technologies, as well as to adapt and transform the system of agrarian education in compliance with them.

\section{Data and methods}

Methodology of the study involves such important principles of cognition as scientificity, objectivism and complexity of scientific analysis. Nature of the tasks set by the authors necessitated the use of the following methods: systematization, periodization, problemchronological analysis, comparative analysis, integrated approach to source study on the given topic.

The analyzed and used materials include scientific research of Russian and foreign scholars, foresight studies, analytical documents of international organizations, State institutions, institutes, research centers, associations and foundations, such as: World economic Forum (WEF), Organization for economic cooperation and development (OECD), research organization McKinsey Global Institute [1, 3, 14, 1620].

The research is aimed at determining the main directions of transformation of agrarian education system both structurally and substantively under the influence of the digital economy and Industry 4.0.

\section{Results and discussion}

Today, it is difficult to find a universal definition of the concept of "digital economy". Back in 1995, American computer scientist Nicholas Negroponte (University of Massachusetts) introduced the term "digital economy" to refer to the transition from the movement of atoms to the movements of bits, thus contrasting the concept of virtuality associated with immateriality of goods with the concepts of raw materials and transport. Some Russian researchers compare the digital economy with the virtual environment, which complements the actual reality.

The others support the classical approach and argue that the digital economy is a phenomenon based on digital technology and is limited by the field of electronic goods and services: media content, telemedicine or distance learning. According to the second approach, the digital economy also includes manufacturing process which involves the use of digital technology: Internet of things and smart factory, artificial intelligence and robotics [9].

In other words, everything that characterizes Industry 4.0 is added to the definition. The concept of Industry 4.0 is used in the context of the fourth industrial revolution. Many experts believe that it is happening now, as a result of the formation and development of cyber-physical systems (CPS). The conceptual ideas of Industry 4.0 include digitalization as a global trend, which permeates all technological chains and assets, allowing to create new goods and services and increase their value [21-23].

It is reasonable that the WEF report on global competitiveness (2016-2017) places emphasis on investment in digital technologies, including the development of infrastructure for efficient markets, skills and competencies [24].

The State program "Digital economy in the Russian Federation" gives the following definition: "digital economy is a model of economic management, built with the maximum use of computer technology, which will bring human daily life, labour relations, economic structure, and education to a new level" [24].

The WEF has proposed a special international network readiness index. It is used to estimate countries' readiness for the digital economy (Global information technology, 2016). This index allows estimating the productivity of digital technology use by economies in order to improve competitiveness and welfare, as well as the factors having impact on digital economy's development.

In the present study, Russia ranks only 41st in terms of readiness for the digital economy and 38th in terms of economic and innovative results of digital technology use. This shows a significant gap about 5-8 years between Russia and the leading countries. At the same time, despite lagging behind the OECD (Organization for economic cooperation and development) by 1.5 times, Russia leads among countries [15].

Russia's entry to the digital global system is slowed down by a number of problems: 
- Russia's lagging behind in breakthrough technologies from developed countries that have been successfully developing the sixth technological mode.

- low level of involvement of Russian enterprises in global cooperation, technological transfers, affiliate networking;

- irregular and inactive attention of the authorities and business to introducing information technology into production infrastructure and business processes;

- acute shortage of staff with competencies and skills in the field of Industry 4.0 and the lack of digital culture.

It is obvious that the solution of these problems is primarily related to human capital. In the PWC's report "World review of implementation of the Industry 4.0 conception in industrial companies in 2016", the formation and development of the main technological solutions are given in the form of an algorithm, the key elements of which are: developing customer relationships through digital channels, people, and education as critical to digital transformation [17].

It is obvious that the digital economy and Industry 4.0 will affect all spheres of life, including the sphere of agriculture and agrarian economy. Now we observe the wide development of such areas as:

- Agricultural yielding with the help of genetically modified organisms, more resistant to pests, diseases, droughts, and herbicides.

- Cloning of animals for special tasks (receiving biologically active preparations, veterinary research, etc.).

- Transition from manually operated agricultural machinery to autopilot machinery based on microgeolocation and self-learning robots, including the introduction of monitoring drones and "electronic shepherds" for unmanned grazing.

- Growing demand of agrobusiness and environmentally responsible consumers for technological solutions in the sphere of integrated remote monitoring of agricultural production compliance with environmental requirements and tracking the supply chain of products (including GPS / GLONASS-marking)

- Formation of complexes of technological solutions and equipment, allowing for creation of the artificial agrobiocenoses on industrial scale (forestrypasture and forestry-agricultural-pasture) and others. This in turn will result in the emergence of new professions and will create demand for new competencies.

Even today we can talk about the need to develop master's programs in such areas as: smart farming; robotization of production in AIC; urban agriculture and "vertical cultivation"; intelligent technologies of food waste processing and resource saving; genetic engineering and cultivation of high-yield crops; IoT in agriculture; bioeconomics and biotechnology; geo-and bioinformatics, etc.

For successful training of engineering and scientific personnel for the digital transformation of agricultural production, new professional standards are also needed, such new professions as: agro-informatics, agrocybernetics, GMO-agronomist, city farmer, agricultural ecologist, system biotechnologist, energy auditor, robotic systems engineer in agriculture, living systems architect, virtual agricultural environment architect, meteorologist, agricultural robot designer, park ecologist, agronomisteconomist, foodnet -specialist, operator of automated agricultural machinery, specialist in precision agriculture, etc.

The development of the digital economy in AIC, provided by modern technologies, including robotics and artificial intelligence, entails high productivity, increased efficiency, security and convenience. But on the other hand, it also raises complex questions on the wider impact of digitalization on the agricultural labor market, skills and competencies, and therefore on the agricultural education system. According to some estimates, almost half of modern professions can be automated by 2025 , including many agricultural $[15,25,26]$.

According to the Agency for strategic initiatives of Russia (ASI) to the professions of tomorrow and the day after tomorrow can be attributed:

Until $2020 *$

- $\quad$ System biotechnology

- $\quad$ IT-medic

- Energy auditor

- Marine infrastructure systems engineer

- Robotic systems engineer

- $\quad$ Project Training Organizer

- Small Aviation Production Engineer, etc.

After 2020*

- Architect of living systems

- Virtual reality architect

- Meteorologist

- Medical Robot Designer

- $\quad$ Park ecologist

- Educational Path Developer

- $\quad$ Aircraft Recycling Technologist [26].

As we can see, even in the name of professions you can see the synergy of different branches of knowledge, both natural science and humanitarian content. Meanwhile, according to Professor of theoretical physics, Michio Kaku, the list of professions that can not be replaced immediately or completely by artificial or automated systems is quite wide. And it makes sense to think about them in advance. These include all activities related to creativity, intuition, social communication. Among them are different types of design, programming, technical and medical diagnostics, the work of investigators and marketers.

In addition, there remains a large list of "working professions" that are rather difficult to robotize and which may be associated with craft skills and fine motor skills. In fact they can be called workers only conditionally, since their level of complexity also rises and often in order to work today in working qualifications, for example, the oil and gas industry needs higher education [9, 26].

Just as Klaus Schwab emphasized in his speech, the fourth industrial revolution will finally change not only what we do and how we produce, but also who we are in the biological and social senses. It will affect our personality and all issues related to it: our sense of privacy, our concepts of ownership, our consumption 
patterns, the costs of work and leisure, and how we develop our career, improve skills, meet people, and maintain relationships [12]

The list is endless, but so far it is only bound by our imagination. Similarly, revolutions in biotechnology and IT, which are redefining what it means to be human, pushing aside the current thresholds of life expectancy, health, cognition and opportunity, the 4th revolution as a whole will force us to reconsider our moral and ethical boundaries [7].

In this regard, in addition to professional competencies, the so-called meta-competencies come to the fore, or they are often called soft or "soft" competencies. The following abilities and willingness are usually attributed to them:

- to lifelong education, continuous personal and professional development and mobility, striving for the new;

- critical thinking and rational reflection;

- to reasonable risk, enterprise and creativity;

- the ability to work independently and as a team, in a highly competitive environment, in a high uncertainty mode and a quick change of task conditions;

- $\quad$ proficiency in foreign languages for effective communication in the global economy;

- digital and functional literacy.

- emotional intelligence

Technology is developing rapidly, but organizations and skills tend to move more slowly. In the coming decades, the gap between fast-growing technology and slower human development will widen as exponential improvements in artificial intelligence, robotics, networks, analytics and digitization affect more and more economics and society.

Unfortunately, we have to admit that the education system is not keeping pace with the revolutionary changes in the economy. We are not talking about advanced organizations and companies, but about that vast labor and production market, the vast majority of countries in the world, including Russia.

Many employers, according to the McKinsey expert company, can not find enough employees who would have the necessary skills. A survey they conducted in 9 OECD countries showed that $40 \%$ of employers said lack of skills was the main reason for entry-level vacancies; $60 \%$ stressed that new graduates were not adequately prepared not only in technical competencies but also in soft skills - communication, teamwork and punctuality $[16,27]$.

Today there are serious international studies that suggest which trends in the system of modern and future education will become dominant. These include the following:

- training will become a major daily activity;

- training will be lifelong;

- traditional lecture training will give way to the project type of education;

- there will be a change in the models of education scaling, from the mass segment to the individual.

\section{Conclusion}

In the near future, according to the state program "Digital economy of the Russian Federation", data in digital form will become a key factor in agricultural production and business, as well as the entire socioeconomic sphere. This is due to both global challenges and the need to strengthen the competitiveness of Russia and its regions, improving living standards for the public, economic growth and ensuring food security and national sovereignty.

The priority goals and objectives of the direction related to training of personnel for AIC and agricultural education are: development and formation of basic conditions for training, demanded by the digital economy in AIC; improvement and transformation of the system of agrarian education, providing the digital economy with competent professionals; formation and development of the labor market in AIC, meeting the criteria and requirements of the digital economy; development of a system of motivation for the development of relevant competencies and involvement of personnel in the digital economy of AIC in Russia.

All of the above are serious challenges not only for the labor market and the education system. This primarily concerns teachers and parents, who will have to be actively involved in these changes, understanding their responsibility and the need to comply with it.

\section{References}

1. R. Silberglitt et al., The Global Technology Revolution 2020, In-Depth Analyses: bio/nano/materials/information trends, drivers, barriers, and social implications. Technical Report (RAND, National Security Research Division, Santa Monica, CA, 2006) Retrieved from: http://www.rand.org/pubs/technical_reports/2006/R AND_TR303.pdf

2. A. Ross, The Industries of the future (Simon \& Schuster, 2016)

3. OECD report "Vision 2060: Long-term prospects for global growth" Retrieved from: http://espas.eu/orbis/document/looking-2060-longterm-growth-prospects-world

4. EU framework programme Horizon 2020 Retrieved from: http://eeas.europa.eu/delegations/russia/press_ corner/all news/news/2013/20131213 ru.htm

5. F. Nezhmetdinova, Global challenges and globalization of bioethics Croat Med. J. 54(1), 8385 (February 2013) doi: 10.3325/cmj.2013.54.83

6. F Nezhmetdinova et al., Global challenges for agrarian sector of Russian economy and it human resources Revista ESPACIOS 39(26) (2018)

7. A look at education 2016. OECD indicators, Retrieved from: http://www.oecd.org/edu/education -at-a-glance-19991487.htm16 
8. B. Bobrovnikov, Digital economy. It was 2016 Retrieved from: http://www.apkit.ru/files/apkit_ meet2016_DEconomy_Bobrovnikov2.pdf

9. A. V. Babkina, Digital economy and industry 4.0: challenges and prospects: proc. of the sci.-pract. conf. with int. participation (Polytechnic university, 2017)

10. A. Komissarov, Technological Renaissance: The fourth industrial revolution Retrieved from: http://www.vedomosti.ru/opinion/articles/2015/10/1 4/612719-promishlennaya-revolyutsiya

11. T. Gromova, The Power Of Industry 4.0 Retrieved from: http://fastsalttimes.com/sections/obzor/ 522.html

12. K. Schwab, The Fourth Industrial Revolution: what it means, how to respond Foreign Affairs (December 2015) Retrieved from: www.foreignaffairs.com/ authors/klaus-schwab

13. 10 breakthrough technologies of 2017 Retrieved from: https://www.technologyreview.com/lists/ technologies/2017/

14. WEF report "the Future of work and employment 2016" Retrieved from: http://www3.weforum.org/ docs/WEF_Future_of_Jobs.pdf

15. State program "Digital economy of the Russian Federation" Retrieved from: http://static. government.ru/media/files/9gFM4FHj4PsB79I5v7y LVuPgu4bvR7M0.pdf

16. Breakthrough technology: achievements that will transform life, business and the global economy (McKinsey Global Institute) Retrieved from: http://www.mckinsey.com/insights/business_technol ogy/disruptive_technologies

17. World review of the implementation of the concept "industry 4.0" for 2016, Retrieved from: www.PWC.com/industru4.0

18. Future of manufacturing - GOV.UK, Retrieved from: https://www.gov.uk/government/collections/ future-of-manufacturing
19. Programs: Manufacturing.gov. Retrieved from: https://www.manufacturing.gov/programs/

20. Man and Machine in Industry 4.0. How Will Technology Transform the Industrial workforce Through 2025? (The Boston Consulting Group, Inc. 2015)

21. A.P. Dobrynin, Digital economy - the different ways to the effective use of technology (BIM, PLM, CAD, IOT, Smart City, BIG DATA, and others) Int. J. of Open Information Technologies 4(1), 4-11 (2016)

22. I. Hel, Industry 4.0: what is the fourth industrial revolution? Retrieved from: http://news.ru/businessanalitics/industria-4-0.

23. H. Kagermann, W. Lukas, W. Wahlster, Industrie 4.0: Mit dem Internet der Dinge auf dem Weg zur 4. industriellen Revolution. VDI na - Section 1. Digital economy and industry 4.0: problems and prospects of development 107 chrichten, 13 (2011) Retrieved from: wahlster.de/wordpress/wp-

content/uploads/Industrie_4_0_Mit_dem_Internet_d er_Dinge_auf_dem_Weg_zur_vierten_industriellen_ Revolution_2.pdf

24. World economic forum, Retrieved from: http:/gtmarket.ru/news/2016/09/28/7304

25. World development report 2016. Digital dividend. Review. International Bank for reconstruction and development (World Bank, 2016) Retrieved from: http://wwwwds.worldbank.org/external/default/WD SContentServer/WDSP/IB/2016/01/13/090224b084 05bbc0/1_0/Rendered/PDF/World0developm010divi dends0overview.pdf

26. ASI Atlas of new professions Retrieved from: http://atlas100.EN/

27. Digital business era: border violation Retrieved from: http://www.inesnet.ru/wpcontent/uploads/ 2016/02/Accenture-Technology-Vision-2015rus.pdf

28. The Factory of the Future. Industry 4.0 - The challenges of tomorrow (KPMG AG, 2016) 